\title{
Arginine Synthesis in Proteus mirabilis
}

\author{
By O. W. PROZESKY \\ Department of Microbiology, University of Pretoria, Pretoria, South Africa
}

(Accepted for publication 24 May 1967)

SUMMARY

Twenty-nine arginine auxotrophs of Proteus mirabilis strain 13 have been divided into eight groups which represent different biochemical blocks in the arginine biosynthetic pathway. The mutants were classified according to their growth requirements, syntrophism, accumulation of intermediates and enzyme deficiencies. The steps in the pathway are the same as those of Escherichia coli although mutants will not utilize $N$ - $\alpha$-acetyl-L-ornithine or $N$-acetyl-L-glutamate. However, these two substances were shown to be intermediates. Ornithine is synthesized via the linear route common to enterobacteria and not by transacetylation between $N$ - $\alpha$-acetyl-L-ornithine and Lglutamate as in some other bacteria and yeasts.

\section{INTRODUCTION}

Arginine synthesis has taxonomic significance as differences exist in the biosynthetic steps and enzymic control in various bacteria, yeasts and fungi (Vogel, 1953; Udaka, 1966; Smith, 1966). The arginine pathway as described for bacteria (Vogel, Bacon \& Baich, 1963; Glansdorff, I965; Udaka, 1966) is presented in Fig. I. Some arginine

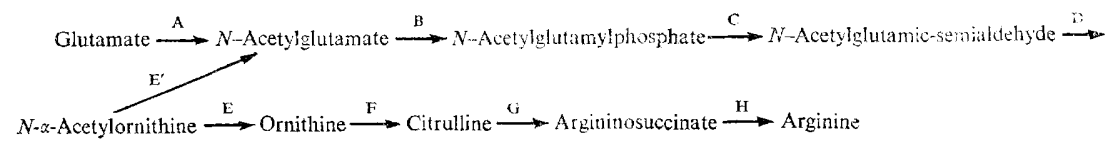

Fig. I. Pathway of arginine synthesis in bacteria. A to $\mathrm{H}$ represent enzymic steps and the sites blocked in the corresponding arg mutants.

mutants of yeasts and fungi respond to proline (Bonner, 1946; Srb, Fincham \& Bonner, 1950) whilst the early intermediates in the bacterial pathway are acetylated and distinct from the precursors in the proline pathway (Vogel, I953; I955). In Micrococcus glutamicus and some other bacteria transacetylation between L-glutamate and $N \alpha$-acetyl-L-ornithine (Fig. I, enzyme E') occurs (Udaka \& Kinoshita, 1958; Vogel \& Vogel, I963; Udaka, I966; Hoare \& Hoare, I966). In these organisms the second enzyme in the pathway, $N$-acetyl- $\gamma$-glutamokinase (Fig. I, enzyme B), is the site of feedback control, whereas in bacteria like Escherichia coli which lack this step the first enzyme, acetylglutamate synthetase (Fig. I, enzyme A), is susceptible (Vyas \& Maas, 1963; Udaka, 1966). The pathways of arginine biosynthesis in E. coli strains K I2, W and B are identical (Gorini, Gundersen \& Burger, I96I ; Maas, 196I; Vogel, I96r) although mutants lacking $N$-acetylornithine- $\delta$-transaminase (Fig. I, enzyme D) have only been isolated in strain w (Vogel et al. 1963). Enzyme repression in E. coli B 
also differs from the mechanism in strains $\mathrm{K} \mathrm{I} 2$ and $\mathrm{W}$ (Gorini et al. I96I). The pathway of arginine synthesis in Salmonella typhimurium resembles that of E. coli (Demerec et al. 1960).

Baumberg, Bacon \& Vogel (1965) concluded that in Escherichia coli $\mathrm{K} \mathrm{I} 2$ the four clustered arginine genes, $\arg E, C, B$ and $H$ have individual repressor recognition sites as repression of these genes was not affected in their mutant which has undergone a separation of these normally closely-linked genes. Vogel \& Bacon (1966) have found that mutations tend to occur concomitantly in functionally-related although not closely linked arginine genes, and because of this they suggested that gene aggregates of such genes may be formed by chromosome folding. The finding of a genetic topography in Proteus mirabilis similar to that of E. coli would confirm the importance and generality of these observations regarding gene sequence and clustering. As a preliminary to genetic studies arginine synthesis in $P$. mirabilis was investigated.

\section{METHODS}

Media. The minimal medium was that of Grabow \& Smit (I 967$)$, with agar ( $1 \cdot 75 \%$, $\mathrm{w} / \mathrm{v}$ ) in solid media. When enriched with a mixture of growth factors (Novick \& Maas, I96I) this medium was used as a complete defined arginine-free medium (AF), to which various concentrations of arginine could be added when required. The complete medium was Difco SS agar for $P$. mirabilis and Difco MacConkey agar for $E$. coli mutants. The broth was that of Coetzee \& Sacks (1960a).

Chemicals. Amino acids, growth factors, arginine precursors, coenzymes and other chemicals were obtained from the Nutritional Biochemicals Corporation, Cleveland, Ohio, U.S.A.; Sigma Chemical Company, St Louis I8, Missouri, U.S.A.; British Drug Houses Ltd., Poole, England or Koch-Light Laboratories Ltd., Colnbrook, Buckinghamshire, England. $N$ - $\alpha$-Acetyl-L-ornithine was synthesized (Vogel, I955) from $N$ - $\delta$-carbobenzoxy-L-ornithine obtained from $\operatorname{Dr}$ Theodor Schuchardt, G.M.B.H. \& Co., München, Germany. o-Amino-benzaldehyde was synthesized from $o$-nitro-benzaldehyde by the method of Albrecht, Scher \& Vogel (I962). Carbamyl phosphate was synthesized according to Jones, Spector \& Lipmann (I955) and extemporate hydroxylamine was prepared from hydroxylammonium chloride (E. Merck A.G., Darmstadt, Germany) by the method of Beinert et al. (I953).

Bacteria. Arginineless mutants of Proteus mirabilis strain 13 and a streptomycinresistant mutant of this organism, I3 str-r (Coetzee \& Sacks, 1960 b) were obtained (Prozesky \& Coetzee, 1966) by treatment with manganese chloride and hydrogen peroxide (Demerec, Bertani \& Flint, 195I). A penicillin enrichment technique (Lederberg \& Zinder, 1948) was followed by replica plating (Lederberg \& Lederberg, 1952). Some of the mutants were selected by the method of Gorini \& Kaufman (1960). The nutritional requirements of mutants were determined auxanographically (Lederberg, I946). Mutant $\arg A \mathrm{I}, B \mathrm{I}$ with two blocks was obtained by transduction with phage 34/I3 (Prozesky, in preparation). E. coli K I 2 arginine mutants w 3422, w 3679 , PA20I were obtained from Dr W. K. Maas (Vyas \& Maas, 1963). The E. coli K I2 arginine mutant GSB I was obtained from Dr N. Glansdorff (Glansdorff \& Sand, I965). A secondary $E$. coli mutant W $4422 \mathrm{P}$ able to grow with acetylglutamate was obtained from mutant $\mathrm{W} 3422$. It has the same phenotype as mutant $\mathrm{W} 3422 \mathrm{~B}$ of Vyas $\&$ Maas (1963) and was selected in the same way. The mutants and their phenotypes 
are listed in Table 1 . Cultures were maintained on nutrient agar slopes at $4^{\circ}$ and the incubation temperature was $37^{\circ}$. Fluid cultures were aerated with sterile air.

Syntrophism. All the Proteus mirabilis and Escherichia coli mutants were tested with one another. Overnight broth cultures of mutants were streaked in parallel about

Table I. Phenotypes of arginineless mutants

\begin{tabular}{|c|c|c|c|}
\hline & Reaction to & Growth response with & \\
\hline Mutants & $\begin{array}{l}\text { Enzyme streptomycin } \\
\text { block (I mg./ml.) ac-glu }\end{array}$ & ac-orn orn $\mathrm{ci}$ & $\arg$ \\
\hline
\end{tabular}

Proteus mirabilis

\begin{tabular}{|c|c|c|c|c|c|c|c|}
\hline $\arg A \mathrm{I}$ & A & $r$ & - & - & + & -i. & + \\
\hline $\arg A 2$ & A & s & - & - & + & + & + \\
\hline $\arg A_{3}$ & A & s & - & - & + & + & + \\
\hline $\arg A 4$ & A & $r$ & - & - & + & + & + \\
\hline $\arg A 5$ & A & $\mathrm{s}$ & - & - & + & + & + \\
\hline $\arg A 6$ & A & s & - & - & + & + & + \\
\hline $\arg A \mathrm{I}, B_{\mathrm{I}}$ & $A+B$ & $\mathrm{r}$ & - & - & + & + & + \\
\hline $\arg B_{\mathrm{I}}$ & B & s & - & - & + & + & + \\
\hline $\arg \mathrm{B}_{2}$ & B & $\mathrm{s}$ & - & - & + & + & + \\
\hline $\arg C \mathrm{I}$ & C & s & -- & - & + & + & + \\
\hline $\arg D_{\mathrm{I}}$ & $\mathrm{D}$ & s & $\ldots$ & - & + & + & + \\
\hline $\arg D_{2}$ & $\mathrm{D}$ & s & - & - & + & + & + \\
\hline $\arg D_{3}$ & D & $\mathrm{s}$ & - & - & + & + & + \\
\hline $\arg D_{4}$ & $\mathrm{D}$ & $\mathrm{s}$ & - & - & + & + & + \\
\hline $\arg D_{5}$ & D & $\mathrm{s}$ & - & - & + & + & + \\
\hline $\arg D 6$ & D & s & - & - & + & + & + \\
\hline $\arg E \mathrm{I}$ & $\mathrm{E}$ & $\mathrm{r}$ & - & - & + & + & + \\
\hline $\arg E 2$ & $\mathrm{E}$ & s & - & - & + & + & + \\
\hline $\arg E_{3}$ & $\mathrm{E}$ & $r$ & $\ldots$ & - & + & + & + \\
\hline $\arg F_{\mathrm{I}}$ & $\mathrm{F}$ & $\mathrm{r}$ & -- & - & - & + & + \\
\hline $\arg F_{2}$ & $\mathrm{~F}$ & $\mathbf{r}$ & - & - & - & + & + \\
\hline $\arg F_{3}$ & $\mathbf{F}$ & $\mathrm{r}$ & .. & - & - & + & + \\
\hline $\arg F_{4}$ & $\mathrm{~F}$ & s & - & - & - & + & + \\
\hline $\arg F_{5}$ & $\mathrm{~F}$ & $\mathrm{~s}$ & - & - & - & + & + \\
\hline $\arg G \mathbf{I}$ & $\mathrm{G}$ & $\mathrm{s}$ & - & - & - & - & + \\
\hline $\arg G_{2}$ & G & s & - & - & - & - & + \\
\hline $\arg H_{\mathrm{I}}$ & $H$ & $s$ & - & - & - & - & + \\
\hline $\arg \mathrm{H}_{2}$ & $\mathrm{H}$ & s & - & - & - & - & + \\
\hline $\arg \mathrm{H}_{3}$ & $\mathrm{H}$ & s & - . & - & - & - & + \\
\hline \multicolumn{8}{|c|}{ Escherichia coli } \\
\hline$W_{3422}$ & A & s & - & + & + & + & + \\
\hline$W 3422 \mathrm{P}$ & A & s & + & + & + & + & + \\
\hline$W_{3679}$ & B & $s$ & - & + & + & + & + \\
\hline GSB I & $C+E$ & $\mathrm{r}$ & $\ldots$ & - & $t$ & + & + \\
\hline PA $20 I^{*}$ & $\mathrm{E}$ & $\mathrm{r}$ & - & - & + & + & + \\
\hline
\end{tabular}

$\mathbf{r}=$ resistant $; \mathrm{s}=$ sensitive $;$ ac-glu $=$ acetylglutamate; ac-orn $=$ acetylornithine orn $=$ ornithine cit $=$ citrulline; arg = arginine $+=$ growth $;-=$ no growth.

* Also requires threonine, leucine, thiamine, histidine.

$2 \mathrm{~mm}$. apart on minimal agar enriched with $0.01 \%$ Difco nutrient broth powder and incubated for $48 \mathrm{hr}$ (Grabow \& Smit, I 967). Results were confirmed by auxanography with isolated accumulated precursors obtained from a representative of each of the $P$. mirabilis mutant types (see below). These precursors were tested for growth response with all the $E$. coli mutants and a representative of each of the $P$. mirabilis mutant types.

Isolation of accumulated precursors. Cultures were grown in $\mathrm{I} 600 \mathrm{ml}$. minimal 
medium containing L-arginine hydrochloride $(8 \mu \mathrm{g} . / \mathrm{ml}$.). L-Citrulline or L-ornithine was substituted for arginine when possible to minimize possible effects of repression or feedback control (Gorini \& Maas, 1958; Vogel, 196I). After incubation for $36 \mathrm{hr}$ at $37^{\circ}$ the cultures were Seitz-filtered and any argininosuccinate, citrulline, ornithine and acetylornithine which had accumulated in the medium was extracted using a column $\left(25 \times 3.5 \mathrm{~cm}\right.$.) of cation exchange resin (Amberlite IR I $20, \mathrm{H}^{+}$form). The column was washed with $500 \mathrm{ml}$. water and eluted with $150 \mathrm{ml}$. N- $\mathrm{NH}_{4} \mathrm{OH}(\mathrm{Grabow}$ \& Smit, 1967). The eluates were vacuum-evaporated to dryness and the residues dissolved in $0.5 \mathrm{ml}$. water for preliminary chromatography. $N$-Acetylglutamic- $\gamma$ semialdehyde and acetylglutamate were concentrated and purified as described by Vogel (I953) and Vyas \& Maas (1963) respectively.

Chromatography. A modification of the technique of Grabow \& Smit (I967) had to be used because of the residual salts content of the sample. Duplicate one-dimensional chromatograms of samples and standards were developed for $\mathrm{I} 6 \mathrm{hr}$ on Whatman No. 3MM paper with $n$-butanol + pyridine + water $(\mathrm{I}+\mathrm{I}+\mathrm{I}$, by vol.) as solvent by the descending technique. Standards were located by spraying with ninhydrin $(0.2 \%$, $\mathrm{w} / \mathrm{v}$, in acetone) and heating at $100^{\circ}$ for $5 \mathrm{~min}$. Acetylglutamate was located with $0.05 \%(\mathrm{w} / \mathrm{v})$ bromcresol-green in $95 \%$ ethanol (Vyas \& Maas, 1963). Corresponding areas on duplicate chromatograms containing the samples were cut out, eluted with water and the eluates vacuum-evaporated to dryness. The residues were taken up in $0.1 \mathrm{ml}$. water and re-chromatographed on Whatman No. I paper in two dimensions. The solvents were: first dimension, $n$-butanol + formic acid + water $(77+\mathrm{IO}+\mathrm{I} 3$ by vol.); second dimension, $n$-butanol + pyridine + water as above. Acetylglutamate gave elongated spots with these solvents when applied to chromatograms in sufficient quantities for clear definition with the bromcresol-green method. This precursor was therefore only chromatographed in one dimension with each solvent which is sufficient for identifying this substance (Vyas \& Maas, I963).

Precursor identification. Substances on chromatograms were identified by position and by mutant response. The mutant response technique was a modification of the method of Winsten \& Eigen (I950). Minimal agar was seeded with about Io ml. washed bacteria from an overnight broth culture of a mutant strain of Escherichia coli or Proteus mirabilis with a known growth response. The seeded medium was poured as plates of $30 \times 30 \times \mathrm{I} \mathrm{cm}$. (Maré, Coetzee \& de Klerk, 1964). Chromatograms were cut into squares, sterilized with ultraviolet light and placed on the agar for $5 \mathrm{~min}$. After removal of the paper the plates were incubated for $48 \mathrm{hr}$ and areas of growth were compared with stained chromatograms of samples and standards which had been developed concurrently. $N$-acetylglutamic- $\gamma$-semialdehyde was identified by its colour reaction with $o$-amino-benzaldehyde and by preparing its hydrazone derivative with 2,4-dinitro-phenylhydrazine (Vogel, 1953).

Enzymes. The enzymes and their assay methods are listed in Table 2. In general the specific activities of enzymes in cell-free extracts of all the auxotrophs were compared with those of the prototroph. However, the wild-type level for glutamate acetylation (enzyme A) was measured with resting cell suspensions of mutant $\arg B$ I (Vyas \& Maas, 1963) and the mutant enzyme level was determined with the double mutant, $\arg A \mathrm{I}, B \mathrm{I}$; acetylglutamate was assayed with Escherichia coli $\mathrm{w} 3422 \mathrm{P}$. To eliminate interference from acetylornithinase, transacetylation between acetylornithine and glutamate (enzyme $\mathrm{E}^{\prime}$ ) was measured in mutant $\arg E \mathrm{I}$. 


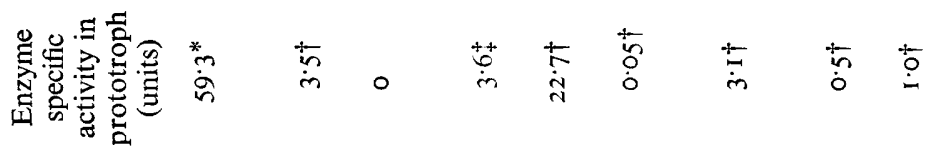

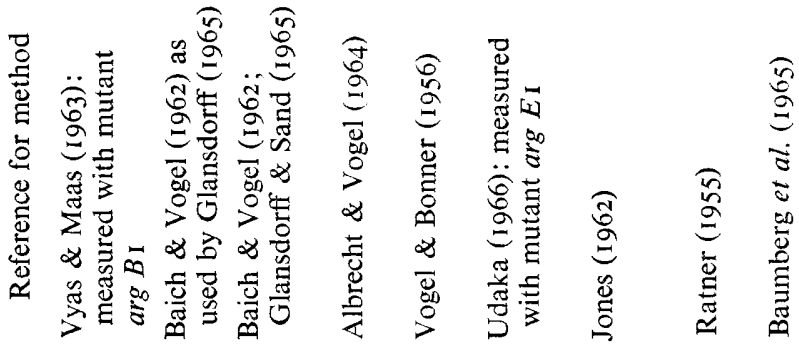

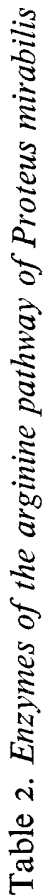

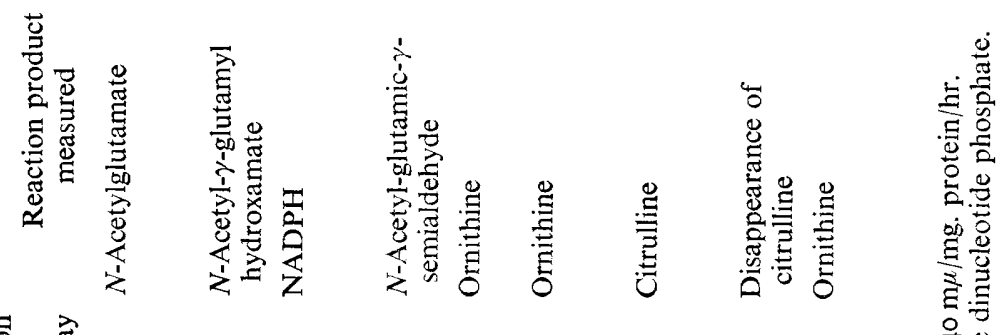

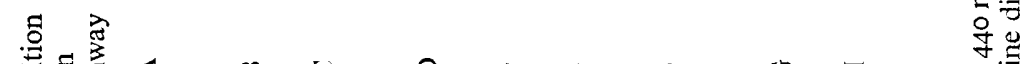

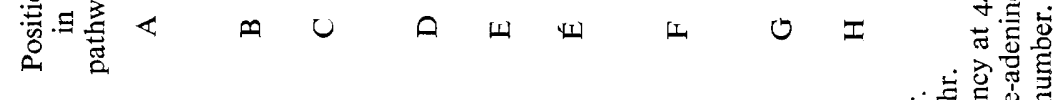

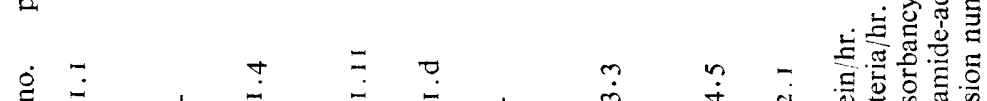

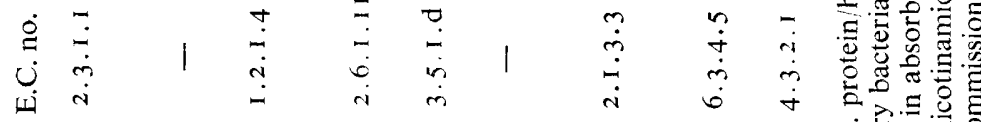

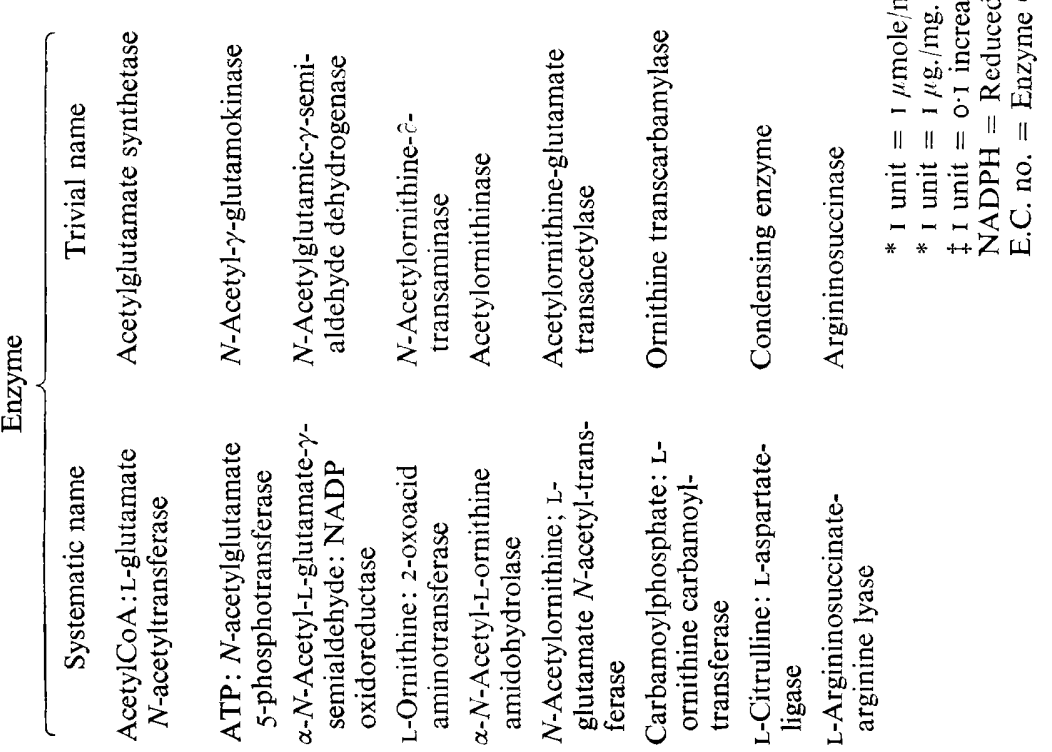


Preparation of cell-free extracts. Organisms (approximately $500 \mathrm{mg}$. dry wt) were harvested from $1600 \mathrm{ml}$. of medium AF supplemented with L-arginine hydrochloride $(8 \mu \mathrm{g} . / \mathrm{ml}$.) after $36 \mathrm{hr}$. They were washed twice in the buffer recommended for the enzymic assay (Table 2) and resuspended in $25 \mathrm{ml}$. of the same buffer. Suspensions were disrupted in a Raytheon model SIO2A oscillator (9 kcyc./ $/ \mathrm{sec}$. for $45 \mathrm{~min}$.) and centrifuged at $30,000 \mathrm{~g}$ for $30 \mathrm{~min}$. in a Sorvall SS-4 centrifuge. The supernatant fluid was dialyzed against $2 \mathrm{l}$. of the corresponding buffer with 2 changes. The above manipulations were all performed at $4^{\circ}$. Protein content of the extracts was determined by the method of Gornall, Bardawill, \& David (1949).

\section{RESULTS}

Arginineless auxotrophs. A total of 103 arginine-requiring mutants were obtained from 30 isolation experiments and a group of 29 mutants was chosen for investigation on the basis of one phenotype per isolation.

Growth requirements. The growth requirements of these mutants are given in Table I, and three classes of Proteus mirabilis mutant can be distinguished. They responded to ornithine, citrulline or arginine and appear to be blocked in the synthesis of ornithine, the conversion of ornithine to citrulline or the conversion of citrulline to arginine, respectively (Fig. I). None of the mutants responded to glutamate, acetylglutamate, acetylornithine, acetylglutamic- $\gamma$-semialdehyde, argininosuccinate or proline. No secondary mutants (Vyas \& Maas, 1963) able to grow with acetylglutamate, acetylornithine, acetylglutamic- $\gamma$-semialdehyde or argininosuccinate were isolated after exposure to these intermediates, although the selection method proved satisfactory for the isolation of Escherichia coli $\mathrm{w} 3422 \mathrm{P}$ from mutant $\mathrm{w} 3422$.

Syntrophism. The above results were confirmed by studies of syntrophism with all the mutants; the same three mutant classes were identified. Mutants subsequently defined as types $G$ and $H$ fed all other mutants but were fed by none. Type $F$ mutants were fed by type $G$ and $H$ mutants and fed the class of mutants which included types $A, B, C, D, E$. This latter class of mutants did not feed the other classes of mutant nor was syntrophism exhibited between pairs of mutants within this class despite the fact that they accumulate precursors (see below). These mutants were further classified by syntrophism tests with well-characterized $A, B$ and $E$ mutants of Escherichia coli. Proteus mirabilis mutants types $F, G$ and $H$ fed all the $E$. coli mutants, while none of the $E$. coli mutants fed any of the $P$. mirabilis mutants. Proteus mirabilis $E$ mutants fed $E$. coli $A$ and $B$ mutants but not $E$ mutants. Proteus mirabilis $B$ and $C$ mutants only fed the secondary $E$. coli mutant of type $A$ (W3422 P which responds to acetylglutamate). Proteus mirabilis $A$ and $D$ mutants did not feed any $E$. coli mutants nor did the $P$. mirabilis $C$ mutant feed the $E$. coli type $B$ mutant. The results of syntrophism tests with the auxanographic technique gave identical results. Positive identification of the following groups of mutants was possible on the basis of growth response and syntrophism: $A+D ; B+C ; E ; F ; G+H$.

Accumulation of precursors. All the mutants were tested for accumulation of intermediates. Apart from group arg $A$ mutants the other groups accumulated preceding precursors in the medium. Only in the case of $\arg H$ mutants was more than one accumulated precursor identified. The precursors, their $R_{F}$ values, the mutants which excrete them and the mutants used for their identification are listed in Table 3. The 


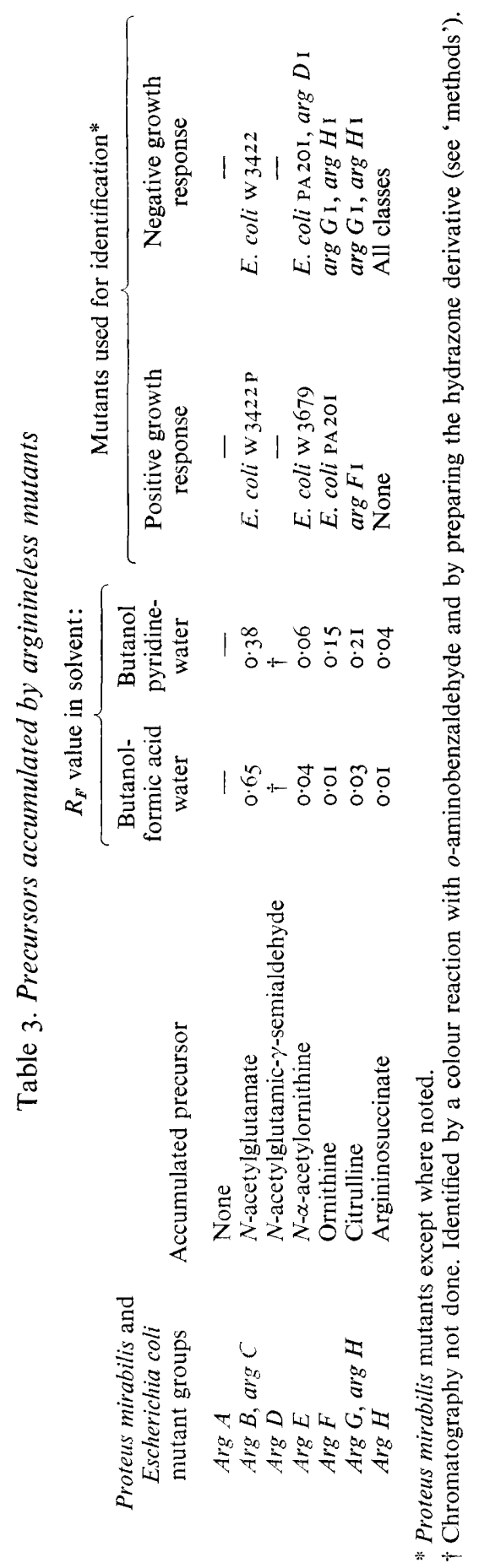


results of the growth requirement experiments, syntrophism tests and accumulation studies made it possible to identify the following groups of mutants: $A ; B+C ; D$; $E ; F ; G ; H$. Distinction between the $B$ and $C$ mutants could only be made by enzyme assays.

Enzyme studies. Seven enzymes in the pathway could be demonstrated in the wildtype organism (Table 2), while all the mutants in each of these seven mutant groups showed complete absence or only traces of the corresponding enzyme activity. The enzyme deficiencies in these mutants positively confirmed their classification based on the results of the preceding investigations. These results also made a distinction between the $\arg B$ and $\arg C$ mutants although $N$-acetylglutamic- $\gamma$-semialdehyde dehydrogenase (enzyme $C$ ) could not be demonstrated. Unsuccessful attempts were made to demonstrate it alone and also in combination with enzymes B or D as for Escherichia coli (Baich \& Vogel, 1962; Glansdorff \& Sand, 1965). Previous work with Proteus mirabilis strain I8 also yielded negative results (Smith, 1966). Failure to demonstrate enzyme $\mathrm{C}$ may be due to oxidation of reduced nicotinamide-adenine dinucleotide phosphate (Smith, 1966) and attempts to separate it from this activity were unsuccessful. However, mutant $\arg C_{\mathrm{I}}$ has the wild-type level of $N$-acetyl- $\gamma$ glutamokinase (enzyme B), activity while enzyme B activity is completely lacking in $\arg B$ mutants. The low level of acetylornithine-glutamate transacetylase (enzyme $\mathrm{E}^{\prime}$ ) and the high level of acetylornithinase (enzyme E) found indicate that the transacetylation reaction probably does not participate in the proteus pathway. The absence of any $\arg E^{\prime}$ mutants is additional evidence for this conclusion.

\section{DISCUSSION}

The findings indicate that the route of arginine synthesis in Proteus mirabilis is identical to that found in Escherichia coli and Salmonella typhimurium (Demerec et al. I960; Vogel et al. 1963; Baumberg et al. 1965). The proteus mutants differ from the E. coli mutants by their inability to grow with acetylornithine. However, it appears that this substance is an intermediate in the pathway because it is accumulated by $\arg E$ mutants and it is the substrate for acetylornithinase (enzyme E) which is present in $P$. mirabilis. The failure of mutants to respond to acetylglutamate is in accordance with similar findings in S. typhimurium (Demerec et al. 1960). Secondary mutants of $E$. coli are able to utilize acetylglutamate which may reflect the acquisition of permeability for this substrate; an acetylornithine permease has been identified in E. coli (Vogel, 1960). Consequently, it appears that P. mirabilis is cryptic (Cohen \& Monod, I957) for acetylornithine and acetylglutamate. Although some experimental conditions were different the specific activities for the enzymes in the arginine biosynthetic pathway (Table 2) are similar to those reported for E. coli (Vyas \& Maas, I963; Glansdorff \& Sand, I965; Vogel \& Bonner, I956; Udaka, I966 and Gorini, I963). The low specific activity of enzyme $\mathrm{E}^{\prime}$ (Table 3 ) indicates that transacetylation between acetylornithine and glutamate does not play an important part in the biosynthesis of arginine in $P$. mirabilis. Udaka (1966) encountered a similar situation with $P$. vulgaris. The inability to demonstrate $N$-acetylglutamic- $\gamma$-semialdehyde dehydrogenase activity in $P$. mirabilis does not exclude the existence of two steps between acetylglutamate and $N$-acetylglutamic- $\gamma$-semialdehyde (Baich \& Vogel, I962). There is strong evidence that reaction $\mathrm{C}$ (Fig. I) exists: Mutant $\arg C_{\mathrm{I}}$ accumulates acetylglutamate and has 
the wild-type level of $N$-acetyl- $\gamma$-glutamokinase (enzyme B) activity (enzyme B activity is completely lacking in $\arg B$ mutants). The observed syntrophism and accumulation of arginine precursors is in marked contrast with the absence of these eatures in the methionine pathway of $P$. mirabilis strain 13 (Grabow \& Smit, 1967) which indicates that this is a peculiarity of the latter pathway in this organism and not a common property of $P$. mirabilis.

Linked transduction with some of these mutants has been described (Prozesky \& Coetzee, I966) and the genetic studies in progress may allow further comparison between arginine synthesis in Escherichia coli and Proteus mirabilis.

Dr W. K. Maas and Dr B. Glansdorff provided Escherichia coli mutants and kind advice. This work was supported by grants from the South African Council for Scientific and Industrial Research to Professor J. N. Coetzee.

\section{REFERENCES}

Alrrecht, A. M., Scher, W. I., Jun., \& Voriel, H. J. (1962). Determination of aliphatic aldehydes by spectrophotometry. Anal. Chem. 34, 398 .

Al BRECHT, A. M. \& VoGel, H. J. (I964). Acetylornithine- - -transaminase. Partial purification and repression behaviour. J. biol. Chem. $239,1872$.

BAiCh, A. \& VoGEL, H. J. (I962). $N$-Acetyl- $\gamma$-glutamokinase and $N$-acetylglutamic- $\gamma$-semialdehyde dehydrogenase: Repressible enzymes of arginine synthesis in Escherichia coli. Biochem. biophys. Res. Comm. 7, 49I.

Baumberg, S., BaCON, D. F. \& VoGel, H. I. (1965). Individually repressible enzymes specified by clustered genes of arginine synthesis. Proc. natn. Acad. Sci., U.S.A. 53, 1029.

Beinert, H., Green, D. E., Hele, P., Hift, H., von Korff, R. W. \& Ramakrishnan, C. V. (1953). The acetate activating enzyme system of heart muscle. J. biol. Chem. 203, 35.

Bonner, D. (1946). Production of biochemical mutations in Penicillium. Am. J. Bot. 33, 788.

Coetzee, J. N. \& SACKs, T. G. (1960a). Morphological variants of Proteus hauseri. J. gen. Microbiol. 23, 209.

Coetzee, J. N. \& Sacks, T. G. (1960 b). Transduction of streptomycin resistance in Proteus mirabilis. J. gen. Microbiol. 23, 445 .

Cohen, G. N. \& Monod, J. (I957). Bacterial permeases. Bact. Rev. 21, I69.

Demerec, M., Bertani, G. \& Flint, J. (1951). A survey of chemicals for mutagenic action on Escherichia coli. Am. Nat. 85, 119.

Demerec, M., Lahr, E. L., Balbinder, E., Miyake, T., Ishidsu, J., Mizobuchi, K. \& Mahler, B. (1960). Bacterial Genetics. Carneg. Insth. Yi. Bk 49, 426.

GlansDorfF, N. (1965). Topography of co-transducible arginine mutations in Escherichia coli K-I 2. Genetics $\mathbf{5} \mathbf{r}, 167$.

Glansdorff, N. \& SAND, G., (1965). Cordination of enzyme synthesis in the arginine pathway of Escherichia coli $\mathrm{K}$ I2. Biochim. biophys. Acta $108,308$.

GorInI, L. (1963). Symposium on multiple forms of enzymes and control mechanisms. III. Control by repression of a biochemical pathway. Bact. Rev. 27, 182

Gorini, L. \& KaUfman, H. (1960). Selecting bacterial mutants by the penicillin method. Science I3I, 604.

Gorini, L. \& MaAs, W. K. (1958). In A Symposium on the Chemical Basis of Development, Ed.

Gorini, L., Gundersen, W. \& Burger, M. (1961). Genetics of regulation of enzyme synthesis in the arginine biosynthetic pathway of Escherichia coli. Cold Spring Harb. Symp. quant. Biol. 26, 173. W. D. McElroy \& B. Glass, p. 469. Baltimore: The Johns Hopkins Press.

Gornall, A. G., Bardawill, C. J. \& David, M. M. (I949). Determination of serum proteins by means of the biuret reaction. J. biol. Chem. 177, $75 \mathrm{I}$.

Grabow, W. O. K. \& Smit, J. A. (1967). Methionine synthesis in Proteus mirabilis. J. gen. Microbiol. 46,47 . 
HoARE, D. S. \& HoARe, S. L. (I966). Feedback regulation of arginine biosynthesis in blue-green algae and photosynthetic bacteria. J. Bact. 92, 375 .

JONES, M. E. (1962). Carbamyl phosphate synthesis and utilization. Meth. Enzymol. 5, 903.

Jones, M. E., Spector, L. \& Lipmann, F. (I955). Carbamyl phosphate, the carbamyl donor in enzymatic citrulline synthesis. J. Am. chem. Soc. 77, 819.

Lederberg, J. (I946). Studies in bacterial genetics. J. Bact. 52, 503.

Lederberg, J. \& Lederberg, E. M. (1952). Replica plating and indirect selection of bacterial mutants. J. Bact. 63, 399.

LEDERBERG, J. \& ZINDER, N. (I948). Concentration of biochemical mutants of bacteria with penicillin. J. Am. chem. Soc. 70, 4267.

MaAs, W. K. (1961). Studies on repression of arginine biosynthesis in Escherichia coli. Cold Spring Harb. Symp. quant. Biol. 26, I83.

Maré, I. J., Coetzee, J. N. \& DE KleRK, H. C. (I964). Agar electrophoresis of colicines with an Alcaligenes faecalis indicator strain. Nature, Lond. 202, 2 I 3.

Novick, R. P. \& MAAs, W. K. (196r). Control by endogenously synthesized arginine of the formation of ornithine transcarbamylase in Escherichia coli. J. Bact. 81, 236.

Prozesky, O. W. \& Coetzee, J. N. (1966). Linked transduction in Proteus mirabilis. Nature, Lond. 209, I 262.

RATner, S. (1955). Enzymatic synthesis of arginine (condensing and splitting enzymes). Meth. Enzymol. 2, 356.

SмITH, P. F. (I966). Comparative biosynthesis of ornithine and lysine by Mycoplasma and L forms. J. Bact. $92,164$.

Srb, A. M., Fincham, J. R. S. \& Bonner, D. (1950). Evidence from gene mutations in Neurospora for close metabolic relationships among ornithine, proline and $\alpha$-amino- $\partial$-hydroxyvaleric acid. Am. J. Bot. 37, 533.

UDAKa, S. (1966). Pathway-specific pattern of control of arginine biosynthesis in bacteria. J. Bact. 91, 617.

UDAKa, S. \& Kinoshita, S. (1958). Studies on L-ornithine fermentation. I. The biosynthetic pathway of L-ornithine in Micrococcus glutamicus. J. gen. appl. Microbiol. 4, 272.

Vogel, H. J. (1953). Path of ornithine synthesis in Escherichia coli. Proc. natn. Acad. Sci., U.S.A. 39, 578.

Vogel, H. J. (1955). In A Symposium on Amino Acid Metabolism, Ed. W. D. McElroy \& H. B. Glass, p. 335. Baltimore: The Johns Hopkins Press.

Vogel, H. J. (1960). Repression of an acetylornithine permeation system. Proc. natn. Acad. Sci., U.S.A. 46, 488.

VOGEL, H. J. (196I). Aspects of repression in the regulation of enzyme synthesis: Pathway-wide control and enzyme-specific response. Cold Spring Harb. Symp. quant. Biol. 26, I63.

VoGel, H. J. \& BACON, D. F. (1966). Gene aggregation: Evidence for a coming together of functionally related not closely linked genes. Proc. natn. Acad. Sci., U.S.A. 55, 1456.

Vogel, H. J. \& Bonner, M. (1956). Acetylornithinase of Escherichia coli: Partial purification and some properties. J. biol. Chem. $218,97$.

Vogel, R. H. \& Vogel, H. J. (1963). Acetylated intermediates of arginine synthesis in Bacillus subtilis. Biochim. biophys. Acta 69, I74.

Vogel, H. J., BACON, D. F. \& BAICH, A. (I963). Induction of acetylornithine $\delta$-transaminase during pathway-wide repression. In Informational Macromolecules, Ed. H. J. Vogel, V. Bryson \& J. O. Lampen, p. 293. New York: Academic Press.

VYAS, S. \& MAAS, W. K. (I963). Feedback inhibition of acetylglutamate synthetase by arginine in Escherichia coli. Archs. Biochem. Biophys. по0, 542.

Winsten, W. A., EIGEN, E. (I950). Bioautographic studies with use of Leuconostoc citrovorum., 808 I J. biol. Chem. 184, I55. 